\title{
An empirical study on "Financial Inclusion through Self Help Groups Bank Linkage Programme - An Economic Catalyst to Transform Rural India“"
}

\author{
Vanishri R Hundekar \\ $\{$ vanirhj9@gmail.com \} \\ Department of MBA, KLS Gogte Institute of Technology, Belagavi, Karnataka
}

\begin{abstract}
Financial inclusion, an ambitious nation-wide program of GOI under the aegis of World Bank strives to cover every citizen under the ambit of banking \& financial services. SHG was introduced with multiple aims like access to loan, enabling income generation, encouraging savings and eventually empowering the poor. This research aims to measure the penetration of financial inclusion through SHGBLP in the state of Karnataka using financial inclusion index as a yardstick. Parameters viz. bank penetration, credit penetration, and penetration of SHG in various districts of Karnataka have been used to compute financial inclusion index. Study is a combination of empirical and conceptual research illustrating the conjoint relationship between the parameters to determine the rate of financial inclusion through SHGBLP in the state of Karnataka as an anecdote in India per se. The study was conducted in Belagavi district. Statistical tools like reliability test, Pearson's correlation analysis, Chi-square tests are used.
\end{abstract}

Keywords: Self Help Groups Bank linkage programme, Financial Inclusion Index, Self Help Group Penetration, Banks Penetration, Rural India, Financial Services.

\subsection{Introduction:}

The policy of financial inclusion assures boosting economic growth and reducing poverty and inequality remarkably, by mobilizing savings and providing households and firms with greater access to finance for consumption and investment. Financial inclusion can be defined as the "Process of ensuring access to financial services and timely availability of adequate credit needed by vulnerable groups such as weaker sections and low-income groups at an affordable cost"'11] . Financial Inclusion is the novel exemplary model for economic growth which plays a pivotal role in mitigating poverty.The most important aim of financial inclusion is to broaden the ambit of financial activities and financial system to include the marginalized section of the society under formal banking channel[2].One of the important measures adopted by Reserve Bank of India (RBI) to overcome the problem of financial exclusion is by introducing Self Help Group- Bank Linkage Programme (SHG-BLP). The main aim of this programme is to augment the resources of deprived section by facilitating financial access through the formal financial channel. So far the Indian Government has initiated various programmes for supporting poor households[3]. Out of these initiatives SHG model is considered to be the most flourishing, beneficial and widely acknowledged model among the marginalized section in India.Today, in India, Self Help Groups represent a distinctive approach to financial intermediation. This gives 
access to low-cost financial services with a process of self-management and development of SHG members[4].

\subsection{Objectives}

1. To study the status and Progress of Self Help group bank linkage programme in India.

2. To evaluate, different dimensions of measuring the level of financial inclusion led by Self-help Group Bank Linkage Programme.

3. To compute an index of financial inclusion led by self-help group bank linkage programme for the districts of Karnataka to analyze the regional variation in terms of financial inclusion.

4. To determine whether participation in SHGBLP has led to an increase in the level of financial inclusion

\subsection{Scope of the Study}

The study is undertaken in Belagavi, Karnataka. Primary data is collected from SHG groups and their members using a structured questionnaire to determine whether participation in SHGBLP has led to an increase in the level of financial inclusion in the selected region.

\subsection{Significance of the Study}

In India, among all other models the SHG-Bank Linkage Program model isconsidered to be a widespread one as reflected by its record of good rate of loan repayment alongwith facilitation of regular banking accessibility.SHGBLP was perceivedto fill the existing gap in the formal financial network and extending the outreach of banking to the poor [5]. Banks may need to be encouraged as facilitators in extending the SHG movement in the poorer regions. The present study attempts for an in-depth look at Self Help Group their linkage with Bank as an effective tool to provide easy credit to the poor who otherwise elude the benefits of the financial inclusion[6].This study contributes to the body of knowledge by finding out the regional imbalances in terms of financial inclusion among different Districts in Karnataka State by developing a financial inclusion index. The study investigates whether SHG approach has been successful in facilitatingfinancial inclusion of the rural people in the selected region. The study has contributes to the mass of knowledgesignificantly as the findings can be used by the financial institutions, government agencies and policy formulators for better understanding of the trials and tribulations faced by rural people.The study findings will give more inputs to financial institutions to take the necessary steps to facilitate the accessibility of financial services to the rural poor. The findings of this investigation will provide a basis for planning future strategies or change in the current/existing system. The results of the study will be of immense use to the financial institutions and the policymakers by understanding the regional imbalances in terms of financial inclusion.

\subsection{The rationale behind the Study}

This research study has been held to explore if the SHG approach has been successful in the financial inclusion of the rural people. 


\subsection{Need for Financial Inclusion}

Developing countries like India, it is necessary to include the entire section of the society under a single roof of financial services. Financial Inclusion facilitates mobility in savings, investment and thereby encourages economic growth. It provides a platform for inculcating the habit of saving, especially among the marginalized section of the society, which has been living under the constant shade of financial distress, primarily because of the absence of savings, which makes them a vulnerable section[7]. The SHG-BLP initiated by NABARD aims at financial inclusion and credit linking of the borrowers with the formal banking structure. Conversely, the link between the lending bank and the borrowing individuals is not a direct link, but of an indirect nature through an SHG of individuals, consequently, the programme is called the SHGBank Linkage Programme.

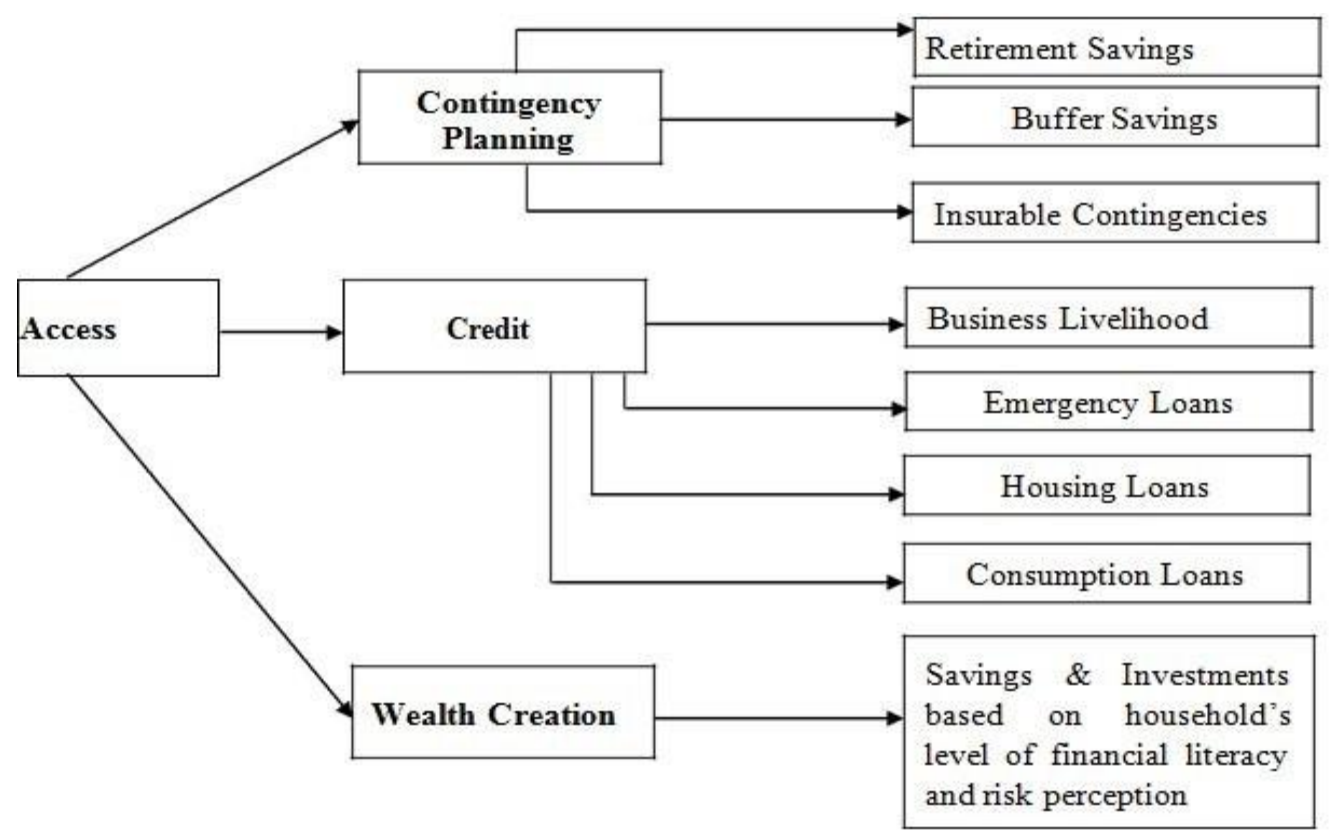

Fig 1: Household Access to Financial Services (Source : www.iosrjournals.org[8])

Households necessitate easy access to financial services for several reasons like for generating buffer, to make savings to hedge against inflation and to plan for unforeseen events, to insure themselves against contingencies. Household also needs access to financial services for consumption and their emergencies. Households require financial services to access to an extensive range of saving and investment products for wealth creation and it all has a link with the level of financial literacy and accessibility of financial services and products available in an economy. The policy initiatives of financial inclusion should focus on catering to such needs of households. 


\section{Conceptual framework of the study}

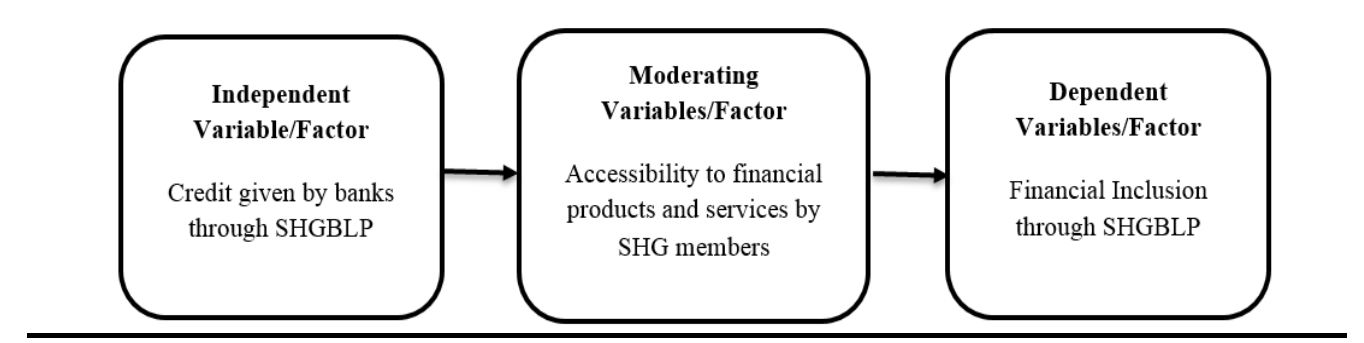

Fig. 2

\subsection{Research Methodology:}

- Identifying the indicators of financial inclusion through SHGBLP, Calculation of Indicator Indexes and Computation of Index of Financial Inclusion.

- Sampling Method: For the purpose of the study, the necessary information is collected from SHG groups and their members. Further, to analyze the accessibility to financial services respondents were interviewed and Random Sampling Method is used to select the respondents. Responses from 100 respondents (20 SHG) were collected and examine the objectives and test the hypotheses.

- Sample Size: 100

- Sampling Frame: Members (Women) of Self Help Groups

- Sampling Unit: Belagavi

- Sampling Population: Belagavi city is considered as the sample population for the study, it is one of the 30 districts ofKarnataka.Under the Stree Shakti scheme, Department of Women and Child Development has launched SHG program on October 18, 2000 in the District.

- Statistical Tools: Reliability test, Pearson correlation analysis, and Chi-square test

- Developing Data Collection instrument:The research tools consisted of a structured questionnaire. A variety of response formats was used in the questionnaire. Formats like multiple choice formats, and Likert's Scale. Part I of the questionnaire designed to elicit the demographic information related to members. Part II of the questionnaire designed to know the awareness and level of financial access to members.

- Determination of Sample Size: Referring to the data of branch banking statistics published by RBI and Gram Panchayatsi.e. District Talukwise number of functioning SHG, 2018 778groups functioning in Belagavi,Karnataka. Since the standard deviation of the population was unknown, random sampling method was used for data collection, and validity purposes using $10 \%$ rule of sampling were collected for analysis. 
- Data Collection: A set of survey questionnaires was administered to create primary data and some secondary data such as the number of SHGs formed and linked to formal banking, savings, credit, recovery related information are obtained from regulatory institutions like NABARD, RBI, CRISIL, Planning commission, Govt. publications and annual reports of MFI's.

\subsection{Literature Review:}

Financial Inclusion through Self-help group bank linkage program gained the momentum in the year 1992. Post which many research studies have highlighted the importance of the higher level of financial inclusion for developing economies, for a country like India it can act as an Economic catalyst to transform rural India. Sibi, M. S., \&Ananth (2017) [9] , mentioned that sound and strong institutions can promote financial inclusion in a sustainable manner. Am a. Cnaan, M.s.Moodithaya, and Femida Handy (2012), in their study, revealed that social and personal deprivation and lack of accessibility contributes to financial exclusion and should be viewed as key barriers to financial inclusion[10] Sharma, Dipasha (2016) found out that the policy and institutional implication of financial inclusion and its various dimensions are found to be the major drivers of an economy [11] .RuchikaBammi (2014) mentioned that bank linkage programme seems to provide various positive impacts on the lives of the rural section in the form of additional savings, improved status in household and community[12]. GupteRajani,BhamaVenkataramani, Deepa Gupta (2012) stated that a financial index has always been an accepted yardstick to measure performance because it allows comparison across countries and establishes the relative ranking [13]. Kajole Nanda and Mandeep Kaur (2017)their study results highlighted that to a large extent the country faces the problem of low financial inclusion. Further, there also is a problem of high interregional/ state variations in terms of financial inclusion [14] . The states in the Southern and Northern regions of the country are the ones that are better financially included than others.A common measure of financial inclusion is the percentage of the population having bank accounts or a number of bank branches per 10,000 population. But these measures are found out to be less effective. To overcome this problem MandiraSarma (2008) in her study proposed an Index of financial inclusion, a multidimensional measure which includes diffusion, widening and deepening which can be used to compare the level of financial inclusion across economies over time. The results showed that a large number of progressing economies also have shown a low level of financial inclusion in terms of penetration and availability of financial services [15] .Considering the same dimensions, a study by Sadhan Kumar Chattopadhyay (2011) on the effectiveness of financial inclusion in West Bengal was undertaken by comparing the performance with other states of India s survey was undertaken for districts of West Bengal, and then financial inclusion index was constructed. As per the index, the West Bengal scored low in financial inclusion [16]. The author was of the opinion that India is yet to see major success in financial inclusion level considering the district level study. Satya R. Chakravarty and Rupayan Pal (2010) presented an axiomatic approach to measuring the level of financial inclusion. At the first stage the authors calculated the level of financial inclusion in 21 countries including India and in the second stage, they calculated the state-level financial inclusion of India on various attributes of financial inclusion [17]. They concluded that at the state level there is remarkable progress from the year 2001-2007 than the period 1991-2001 in terms of financial inclusion. ManiklalAdhikary, SupravatBagli and Papita Dutta (2013) have computed FII for states of India using 6 indicators. They have investigated the impact of SHG centric programs on the level of financial inclusion. 
Their FII values demonstrated that financial inclusion continues to remain elusive for many states of India. They mentioned that SHG centric programmes work on an incremental basis and has a favorable impact on the level of financial inclusion in the long run [18]. M Bhuvana and $S$ Vasantha (2016) in their study have measured an index of financial inclusion using a multidimensional approach similar to proposed by Sarma (2008) considering SHG penetration as one of the dimensions for the state of Tamilnadu. The study showed that the banking services offered to SHG in Tamilnadu and financial inclusion through SHG are measured to be low [19]. It is mentioned in the study SHG model is said to be the successful model for financial inclusion accepted by a marginal section of the society. In a similar study done by Pillai, D., \& Abraham, S. (2017), the author mentioned, SHG can be viewed as a cost-effective, scalable, and sustainable tool for financial inclusion in India [20].

Whilst the significance of financial inclusion is extensively acknowledged, the above literature lack a broad measure which can be used to estimate the level of financial inclusion across the regional level. The present study has made an attempt to fill this gap by developing an index of financial inclusion and a study has been undertaken in Belgavi District to know the level of financial inclusion in the said region led by SHGBLP.

\subsection{Status and Progress of Self Help Group Bank Linkage Programme in India.}

\subsubsection{Self Help Group- Bank Linkage Programme (SHG-BLP)}

SHG-BLP is an Action Research Project initiated by NABARD in 1989 [21]. An SHG starts as a savers group with some saving target. Every group has to save a small amount per month. This saved amount of money is deposited in a bank. The bank where savings are deposited by SHG, examine the performance of the group periodically, and if the performance is found to be good, the group gets credit facility by the bank, without any collateral. Shri ArunJaitley, Finance Minister in his address mentioned that initiative of NABARD led Self-help group bank linkage program, has reached the milestone of 25 years' timeline. The program was officially launched in the year 1992, with a target of linking 500 SHG in a year and has now transformed into the world's largest Microfinance program.[22]

\subsubsection{Models of Self Help Group Bank Linkage Program:}

\section{MODEL I: SHGs formed and Financed by Banks}

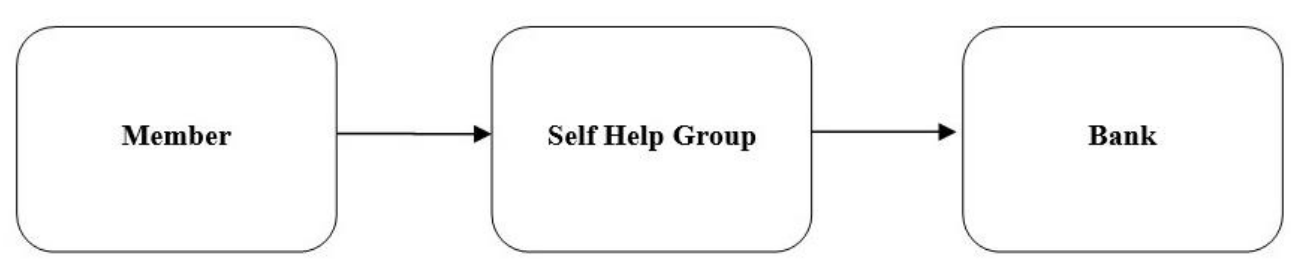

Fig. 3 
In model I, banks themselves act as Self Help Promoting Institutions i.e. engaged in forming and nurturing the groups, opening their savings accounts and providing them bank loans. Group members act as collateral security. In this model the credit is generally made available to the group and members to be financed are identified by the group itself, which takes the responsibility of loan repayment.

MODEL II: SHGs Formed by NGOs and Formal Agencies, but Directly Financed by Banks

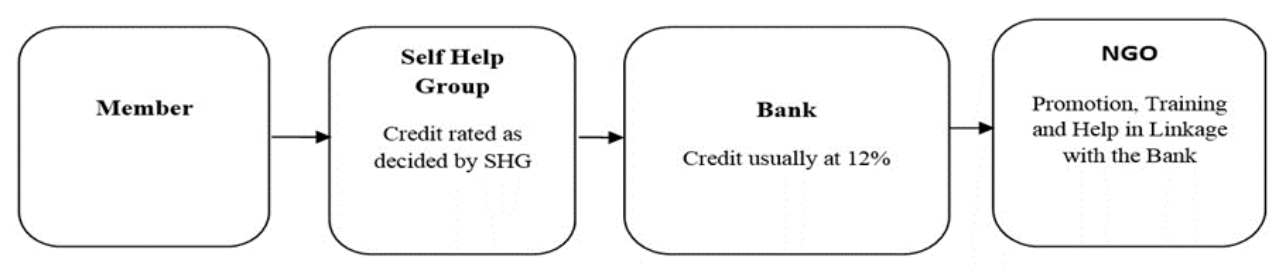

Fig. 4

In model II , NGOs take on the dual role of facilitators and financial intermediaries. They help in formation of SHGs, nurturing them, train them in thrift and credit management. Eventually the NGOs approach banks for bulk loan assistance for on- lending to these SHGs.

MODEL III: SGHs Financed by Banks using NGOs as Financial Intermediaries:

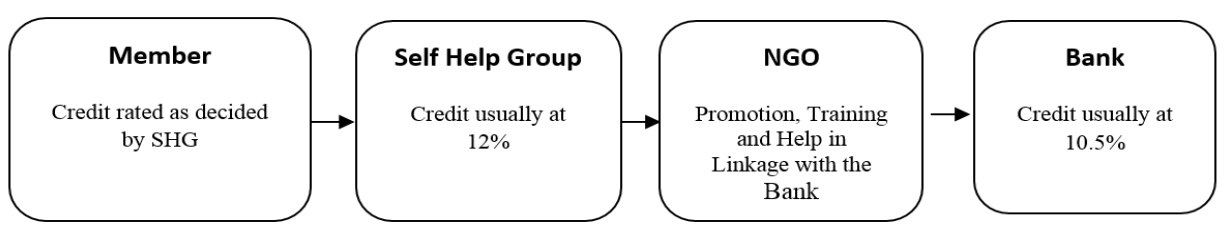

Fig. 5

In model III , NGOs take on the dual role of facilitators and financial intermediaries. They help in formation of SHGs, nurturing them, train them in thrift and credit management. Eventually the NGOs approach banks for bulk loan assistance for on- lending to these SHGs.

\subsection{Features \& Functions of SHGs:}

\section{Table 1}

\begin{tabular}{|l|l|}
\hline $\begin{array}{l}\text { A. Approach of SHG } \\
\text { program }\end{array}$ & $\begin{array}{l}\text { Envisioned as a holistic programme for self-employment and } \\
\text { to enable empowerment opportunity for rural poor by } \\
\text { organizing them in SHGs, capacity building, selection of key } \\
\text { activities, planning of activity clusters, Infrastructure build-up, } \\
\text { Technology and marketing support [ ]. }\end{array}$ \\
\hline
\end{tabular}




\begin{tabular}{|c|c|}
\hline B. Formation of SHG & $\begin{array}{l}\text { A Group consisting of } 10-20 \text { members forms SHG; Special } \\
\text { focus is given on the formation of exclusive women Self-Help } \\
\text { Groups. } 50 \% \text { of the groups formed in each block should be } \\
\text { exclusively for women. SHGs are normally formed by NGOs, } \\
\text { Network of Community-based Coordinators, or team of } \\
\text { dedicated functionaries of the Government. }\end{array}$ \\
\hline $\begin{array}{l}\text { C. Encouragement for } \\
\text { Income Generating } \\
\text { Activities }\end{array}$ & $\begin{array}{l}\text { Committee identifies about } 8-10 \text { farm and non-farm key } \\
\text { activities per block for the individual/SHG Swarozgaris of the } \\
\text { block to choose some of them as the sustainable income - } \\
\text { generating activities. }\end{array}$ \\
\hline $\begin{array}{l}\text { D. Support } \\
\text { (i) Financial Support }\end{array}$ & $\begin{array}{l}\text { Revolving Fund Assistance (RFA) is granted to SHG equal to } \\
\text { their group corpus within the prescribed limit. Subsidy to the } \\
\text { extent of } 30 \% \text { to } 50 \% \text { of the project cost is granted to the } \\
\text { individual beneficiary, and } 50 \% \text { of the project cost for group } \\
\text { level activity is provided within the prescribed limits. Banks } \\
\text { have been advised by RBI to meet the entire credit } \\
\text { requirements of SHG members. }\end{array}$ \\
\hline $\begin{array}{l}\text { (ii) Group Formation and } \\
\text { Nurturing Support }\end{array}$ & $\begin{array}{l}\text { Financial Assistance is extended to NGOs/CBOs/SHPI, etc., } \\
\text { for formation and development of SHGs, as mentioned below. } \\
\text { Rs10, } 000 \text { per SHG is paid for the formation and development } \\
\text { of SHGs in four instalments. } \\
\text { 1. } 20 \% \text { at the beginning of the group formation. } \\
\text { 2. } 30 \% \text { when group qualifies for Revolving Fund. } \\
\text { 3. } 40 \% \text { when group takes up economic activity. } \\
\text { 4. } 10 \% \text { after the start of economic activity and on } \\
\text { adherence of group to repayment of bank loan. }\end{array}$ \\
\hline $\begin{array}{l}\text { iii) Capacity Building } \\
\text { Support }\end{array}$ & $\begin{array}{l}\text { For skill development of members' financial support is } \\
\text { extended to organize training and developmental activities. }\end{array}$ \\
\hline $\begin{array}{l}\text { (iv) Infrastructure } \\
\text { Building Support }\end{array}$ & $\begin{array}{l}\text { There is planned focus on infrastructure build- up, technology } \\
\text { and }\end{array}$ \\
\hline
\end{tabular}




\begin{tabular}{|l|l|}
\hline & $\begin{array}{l}\text { marketing support to make self-employment activity } \\
\text { economically } \\
\text { Sustainable. }\end{array}$ \\
\hline
\end{tabular}

Table: 2 Performance Highlights (Source: The Bharat Microfinance Report 2017 [23])

\begin{tabular}{|c|c|c|}
\hline Indicator & $\mathbf{2 0 1 7}$ & $\mathbf{2 0 1 6}$ \\
\hline No. of Families Reached & 112 million & 103 million \\
\hline No. of SHG & 85.77 lakhs & 79.03 lakhs \\
\hline Total Savings of SHGs & $16,114 \mathrm{C}$ & $13,691 \mathrm{Cr}$ \\
\hline Gross Loan Outstanding & $61,581 \mathrm{Cr}$ & $57,119 \mathrm{Cr}$ \\
\hline Total Loan Disbursed & $38,781 \mathrm{Cr}$ & $37,286 \mathrm{Cr}$ \\
\hline Avg. Loan Disbursed per SHG & $2,04,314$ & $2,03,495$ \\
\hline Avg. Loan Outstanding per SHG & $1,27,017$ & $1,22,242$ \\
\hline NPA & $6.50 \%$ & $6.45 \%$ \\
\hline
\end{tabular}

Chart 1

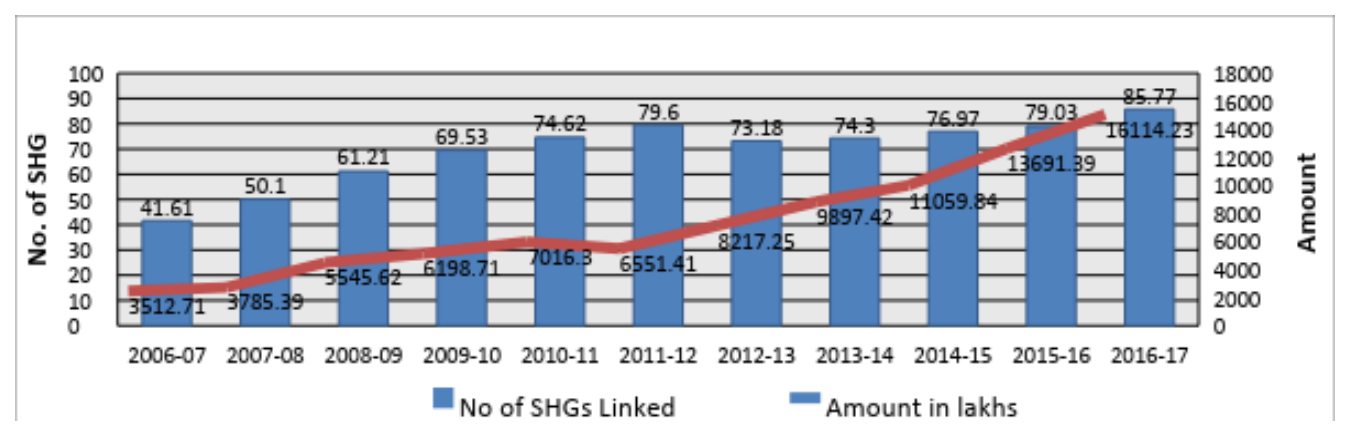

\section{Interpretation}

In Table 2 and chart 1 it is depicted thatSHG model reached to 112-million families and number of SHGs formed so far is 85.77 lakh, but the savings amount is Rs.16, 114 crores i.e. Rs 1, 87,874 per SHG, the total number of credit linked SHG is only 18.98 lakh only i.e. $22.13 \%$. Average loan per SHG is also very less (i.e. Rs. 2, 04,314) means 10,000 to 15,000 per SHG member. NPA is also as high of $6.50 \%$.

\section{Savings under SHG-Bank Linkage Model:}

There is a growth in the number of SHG linkage as well as in the amount of savings done by these SHG under Bank linkage model during the year 2006-2007 to 20011-12. But in the year 2012-13 the number of SHG decline from 79.6 lakh to 73.18 lakh (i.e. 8.1\%), whereas in 2011- 
12 the saving amount experience a decline of 6.7\%, the year 2016-17 has shown remarkable progress.

Table: 3

\begin{tabular}{|c|c|c|c|c|}
\hline Year & & $\begin{array}{l}\text { SHG } \\
\text { Savings with Banks }\end{array}$ & $\begin{array}{l}\text { bursed to SHGs during the year } \\
\text { (SHGs Credit Linkage) }\end{array}$ & $\begin{array}{l}\text { Loans Outstanding } \\
\text { against SHGs }\end{array}$ \\
\hline \multirow{2}{*}{ 2006-07 } & No of SHGs Linked & 41.61 & 11.06 & 28.95 \\
\hline & Amount & 3512.71 & 6570.39 & 12366.49 \\
\hline \multirow{2}{*}{ 2007-08 } & No of SHGs Linked & $50.10(20.40 \%)$ & $12.28(11.0 \%)$ & $36.26(25.3 \%)$ \\
\hline & Amount & $3785.39(7.76 \%)$ & $8849.26(34.7 \%)$ & $16999.91(37.5 \%)$ \\
\hline \multirow{2}{*}{ 2008-09 } & No of SHGs Linked & $61.21(22.2 \%)$ & $16.10(31.1 \%)$ & $42.24(16.5 \%)$ \\
\hline & Amount & $5545.62(46.5)$ & $12253.51(38.5 \%)$ & $22679.84(33.4 \%)$ \\
\hline \multirow{2}{*}{ 2009-10 } & No of SHGsLinked & $69.53(13.6 \%)$ & $15.87(-1.4 \%)$ & $48.51(14.8 \%)$ \\
\hline & Amount & $6198.71(11.8 \%)$ & $14453.3(17.9 \%)$ & $28038.28(23.6 \%)$ \\
\hline \multirow{2}{*}{$2010-11$} & No of SHGs Linked & $74.62(7.3 \%)$ & $11.96(-24.6 \%)$ & $47.87(-1.3 \%)$ \\
\hline & Amount & $7016.30(13.2 \%)$ & $14547.73(0.01 \%)$ & $31221.17(11.4 \%)$ \\
\hline \multirow{2}{*}{ 2011-12 } & No of SHGs Linked & $79.60(6.7 \%)$ & $11.48(-4 \%)$ & $43.54(-9.0 \%)$ \\
\hline & Amount & $6551.41(-6.7 \%)$ & $16534.77(13.7 \%)$ & $36340.00(16.4 \%)$ \\
\hline \multirow{2}{*}{$2012-13$} & No of SHGs Linked & $73.18(-8.1 \%)$ & $12.20(6.3 \%)$ & $44.51(2.2 \%)$ \\
\hline & Amount & $8217.25(25.4 \%)$ & $20585.36(24.5 \%)$ & $39375.30(8.4 \%)$ \\
\hline \multirow{2}{*}{ 2013-14 } & No of SHGs Linked & $74.30(1.53 \%)$ & $13.66(12.02 \%)$ & $41.97(-5.71 \%)$ \\
\hline & Amount & $9897.42(20.45 \%)$ & $24017.36(16.67 \%)$ & $42927.52(9.02 \%)$ \\
\hline \multirow{2}{*}{$2014-15$} & No of SHGs Linked & $76.97(3.59 \%)$ & $16.26(19.03 \%)$ & $44.68(6.46 \%)$ \\
\hline & Amount & $11059.84(11.74 \%)$ & $27582.31(14.84 \%)$ & $51545.46(20.06 \%)$ \\
\hline \multirow{2}{*}{ 2015-16 } & No of SHGs Linked & $79.03(2.68 \%)$ & $18.32(12.67 \%)$ & $46.73(4.59 \%)$ \\
\hline & Amount & $13691.39(23.79 \%)$ & $37286.90(35.18 \%)$ & $57119.23(10.81 \%)$ \\
\hline \multirow[b]{2}{*}{ 2016-17 } & No of SHGs Linked & $85.77(8.53 \%)$ & $18.98(3.60 \%)$ & $48.48(3.74 \%)$ \\
\hline & Amount & $\begin{array}{l}16114.23 \\
(17.69 \%)\end{array}$ & $38781.16(4.01 \%)$ & $61581.30(7.81 \%)$ \\
\hline
\end{tabular}

Source: NABARD Reports "Status of Microfinance in India" (2006-07 to 2016-17) [24]

Figures in parenthesis indicate advance/decline over the previous year, (SHGs in Lakhs/Loan amount in Crores) 


\section{Chart 2}

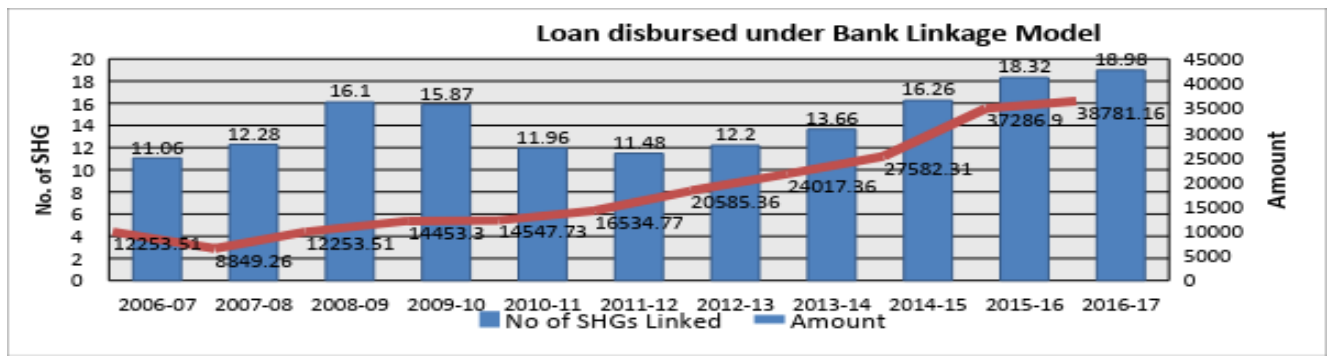

\section{Interpretation}

Loan disbursement under Bank Linkage Model: In table-3and chart 2 it is depicted that in the year 2006- 07 loan amount of 6570.39 crores has been disbursed to 11.06 lakh SHGs, which steadily increases till the year 2008- 09. In the year 2009-10 the SHGs number reduced to 15.87 lakh from the previous year, whereas the loan amount is still increasing but having a decline in its percentage change to $17.9 \%$ from $38.5 \%$ of the previous year which further reduced to $0.01 \%$ in the year 2010-2011. Meanwhile, the no. of SHGs is continuously decreasing with the year; it reached 11.96 lakh in the year 2010-11 and finally its least figure of 11.48 lakh in the year 201112. Subsequently, both the SHGs number and loan amount increased gradually, in the year 201617 no. of SHGs reached 18.98 lakh whereas loan amount reached to 38781.16 crore.

\section{Chart 3}

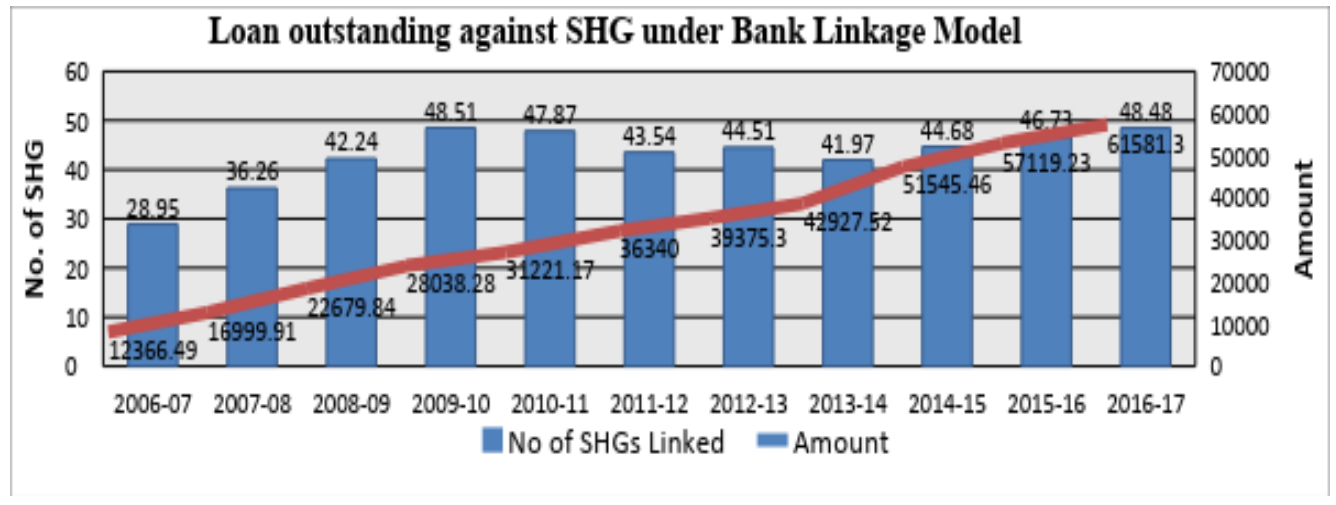

\section{Interpretation}

Loan Outstanding against SHGs: In table 3 and chart 3 in the depicted that, in the year 200607 the loan outstanding against the SHGs was 12366.49 crore which gradually increased with every year, it witnessed the maximum increase of $20.06 \%$ in the year 2014-15. Whereas the number of SHGs also gradually increased to the year 2009-10, it reached to 48.51 lakh from the figure of 28.95 lakh (in 2006-07), it experienced a decline of $1.3 \%, 9 \%$ and $5.71 \%$ in the year 2010-11, 2011-12 and 2013-14 respectively. In the year2016-17 no. of SHGs reached the figure of 48.48 lakh. 


\subsection{Region-wise Status of Bank Credit to SHGs during past Three Years}

Table. 4

\begin{tabular}{|l|l|l|l|l|l|l|l|l|l|}
\hline \multirow{2}{*}{ Regions } & \multicolumn{3}{|c|}{$\mathbf{2 0 1 5 - 1 6}$} & \multicolumn{3}{|c|}{ 2016-17 } & \multicolumn{3}{|c|}{ 2017-18 } \\
\cline { 2 - 10 } & $\begin{array}{c}\text { No. of } \\
\text { SHG }\end{array}$ & $\begin{array}{c}\text { Credit } \\
\text { Given }\end{array}$ & $\begin{array}{c}\text { Avg. } \\
\text { Credit }\end{array}$ & $\begin{array}{c}\text { No. of } \\
\text { SHG }\end{array}$ & $\begin{array}{c}\text { Credit } \\
\text { Given }\end{array}$ & $\begin{array}{c}\text { Avg. } \\
\text { Credit }\end{array}$ & $\begin{array}{c}\text { No. of } \\
\text { SHG }\end{array}$ & $\begin{array}{c}\text { Credit } \\
\text { Given }\end{array}$ & $\begin{array}{c}\text { Avg. } \\
\text { Credit }\end{array}$ \\
\hline N.Eastern & 26037 & 21969 & 84375 & 28961 & 28421 & 98134 & 35017 & 35721 & 102010 \\
\hline Northern & 38106 & 48298 & 126746 & 46567 & 57414 & 123294 & 51800 & 54038 & 104320 \\
\hline Central & 84282 & 119067 & 141272 & 82012 & 67958 & 82864 & 69295 & 55943 & 80732 \\
\hline Western & 112525 & 188632 & 167636 & 106825 & 148819 & 139311 & 128973 & 155099 & 120257 \\
\hline Eastern & 412576 & 349489 & 84709 & 497063 & 473172 & 95194 & 720444 & 908950 & 126165 \\
\hline Southern & 1158797 & 3001235 & 258996 & 1136692 & 3102332 & 272926 & 1255603 & 3508834 & 279454 \\
\hline All India & 1832323 & 3728690 & 203495 & 1898120 & 3878116 & 204314 & 2261132 & 4718587 & 208683 \\
\hline
\end{tabular}

Source: Status of Micro Finance in India 2017-18 (www.nabard.org) [24]

(Total loan disbursed in Lakh; Average loan disbursed in Rs/SHG)

\section{Chart 4}

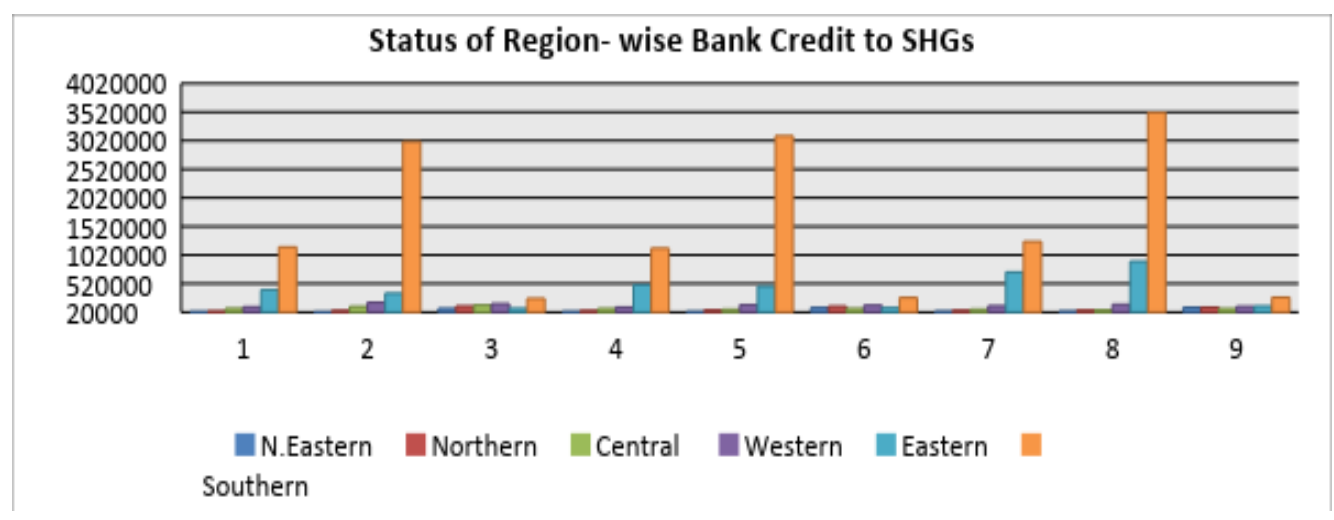

\section{Interpretation}

In table 4 and chart 4 it is depicted that, that there was a decline in the average credit disbursement to SHGs in Northern, Central and Western Regions during 2015-16 and 2016-17. On the other hand, there was a decline in the total loan disbursement to SHGs in Central and Western Regions during 2017-18 as compared 2015-16. These regions contain mostly the priority states where a sizeable rural population belongs to low economic strata. 


\section{Chart 5}

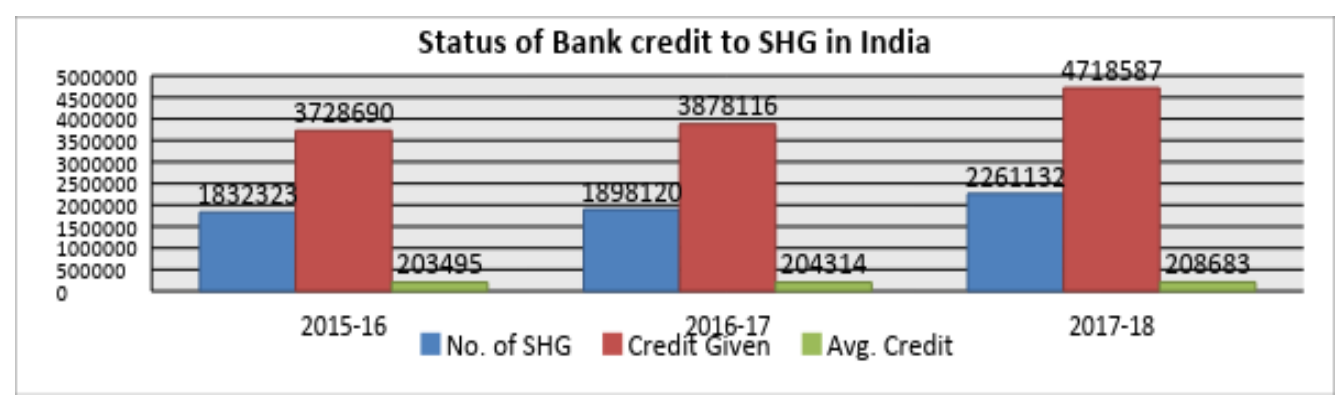

\section{Interpretation}

In chart 5 depicts about Total no of SHGs, Total Credit given and Average credit given, A fall in average credit disbursement indicates a lesser amount of repeat linkages to matured SHGs. This also indicates low credit availability to SHGs from institutional sources which may not be encouraging for SHGs to venture into income generating activities and most of the SHGs may be utilizing the bank loans for consumption purposes.

\subsection{Dimensions to Measure Financial Inclusion through Self Help Group Bank Linkage Programme}

Dimensions considered in the study for determining the Index for Financial Inclusion.

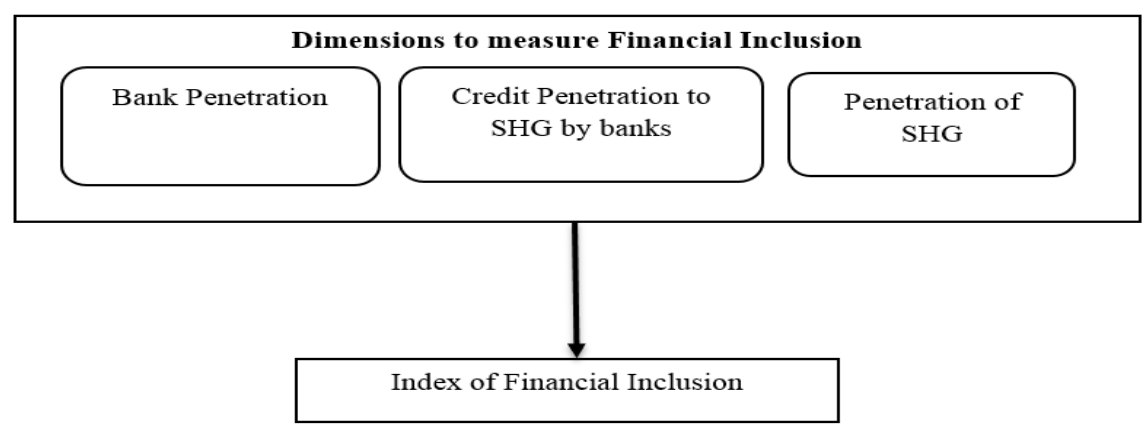

Fig. 6: Dimensions to measure Financial Inclusion Index

Bank Penetration in the Rural Areas (Dimension 1): An inclusive financial system should have a maximum outreach of financial services, that is, financial assistance should penetrate extensively in rural areas. The proportion of people having a bank account is a measure of banking penetration.

Credit Penetration for Self Help Groups (Dimension 2): The main aim of SHG-BLP is to facilitate easy accessibility of credit to the rural people at a very less operational cost. Revolving Fund Assistance (RFA) is granted to SHG equal to their group corpus within the prescribed limit. Subsidy to the extent of $30 \%$ to $50 \%$ of the project cost is granted to the individual beneficiary, and $50 \%$ of the project cost for group level activity is provided within the prescribed 
limits. Banks have been advised by RBI to meet the entire credit requirements of SHG members. [15]

Penetration of SHG (Dimension 3): A large number of beneficiaries are participating in the programme and undoubtedly, it is the widely accepted microfinance model in India.

\subsection{Index of Financial Inclusion through Self Help Groups Bank Linkage}

Index of Financial Inclusion (IFI) is computed to measure the degree of financial inclusion and the growth of financial inclusion plans implemented in India [25]. In this study the degree of financial inclusion through the progress of SHG-BLP is analysed, to find out the role of this programme in broadening financial inclusion. In order to compute a financial inclusion index at a district level, this paper closely follows the methodology proposed by CRISIL. In this study, the index consists of three different dimensions with associated parameters, the reliability will be found for each different parameters consisting of different units of measurements. Hence it has to be normalized by using the below-listed formula called Min-Max Method of Normalization [26].

\section{Equation 1:}

$$
X_{i}(\text { Normalization })=\frac{X_{i}-X(\operatorname{Min}) x 100}{X(\operatorname{Max})-X(\operatorname{Min}}
$$

$X_{i}$ represents the value of the parameter for the particular district ' $i$ '.

$X$ (Min): the minimum value that has been observed over all the districts for a particular parameter.

$X$ (Max): the Maximum value that has been observed over all the districts for a particular parameter.

The data for each parameter of all the districts have been converted between the numbers of 0 to 100 by using the Min-Max Method of Normalization. As per this methodology, 100 indicate complete inclusion for a particular parameter of the district and 0 is the complete exclusion for a particular parameter of the district. The index value of financial inclusion through SHG-BLP for the various districts Karnataka state is measured using the below-mentioned formula as given by the CRISIL Inclusix.

\section{Equation 2:}

Index for Financial Inclusion

$$
=\frac{100-\sqrt{(100-B P)^{2}+(100-C P)^{2}+(100-S H G)^{2}}}{\sqrt{3}}
$$


Table: 5

\begin{tabular}{|l|l|l|}
\hline \multicolumn{1}{|c|}{ Dimension } & \multicolumn{1}{|c|}{ Significance } & \multicolumn{1}{c|}{ Parameters } \\
\hline $\begin{array}{l}\text { Bank } \\
\text { Penetration }\end{array}$ & $\begin{array}{l}\text { Measures the accessibility to financial services } \\
\text { in a particular district }\end{array}$ & $\begin{array}{l}\text { Number of Bank Branches per } \\
\text { 1lakh population in the district }\end{array}$ \\
\hline $\begin{array}{l}\text { Credit } \\
\text { Penetration }\end{array}$ & $\begin{array}{l}\text { Measures the access to credit facilities given to } \\
\text { SHG in particular districts }\end{array}$ & $\begin{array}{l}\text { Credit given by banks to SHG per 1lakh } \\
\text { population in the district }\end{array}$ \\
\hline $\begin{array}{l}\text { Penetration of } \\
\text { SHG }\end{array}$ & $\begin{array}{l}\text { Measures the number of members existing in } \\
\text { SHG in particular districts }\end{array}$ & $\begin{array}{l}\text { Number of Members in SHG per 1lakh } \\
\text { population in the district }\end{array}$ \\
\hline
\end{tabular}

Source: Constructed by Author

\subsection{Financial Inclusion Index (FI) as a Research Methodology}

The main reason to use FII as a research methodology in this study is because; it addresses core necessities such as banking penetration, savings, borrowings, remittance and payment to financially include the excluded, that will assist in measuring and investigating the progress of financial inclusion for a particular district, a state, and the Nation as well. Consequently, the current status of financial inclusion for a particular region can be identified where this index is applied [27].

\subsection{CRISIL Inclusix Index scores of financial inclusion:}

CRISIL Inclusix an index for financial inclusion proposed by Credit Rating Information Services of India Limited (CRISIL) with the support of Ministry of Finance, India, has assigned levels of financial inclusion based on four levels of scores [4]. It is being tabulated below.

Table: 6

\begin{tabular}{|c|c}
\hline CRISIL Inclusix Score & Level of Financial Inclusion \\
\hline 55.0 and above & High \\
\hline 40.1 to 55.0 & Above Average \\
\hline 20.0 to 40.0 & Below Average \\
\hline 25.00 and below & Low \\
\hline
\end{tabular}

Source: CRISIL Inclusix. Financial Inclusion. (2018, August).

\subsection{Index of Financial Inclusion (IFI)}

Table 7 indicates the level of financial inclusion in various districts of Karnataka. Crisil Inclusix Scores methodology is applied for computation of index, which is developed by CRISIL. Ranks 
have been assigned to various districts of Karnataka after computing the overall Financial Inclusion Index taking into consideration the below-mentioned dimensions.

Table: 7 Index of Financial Inclusion (IFI)

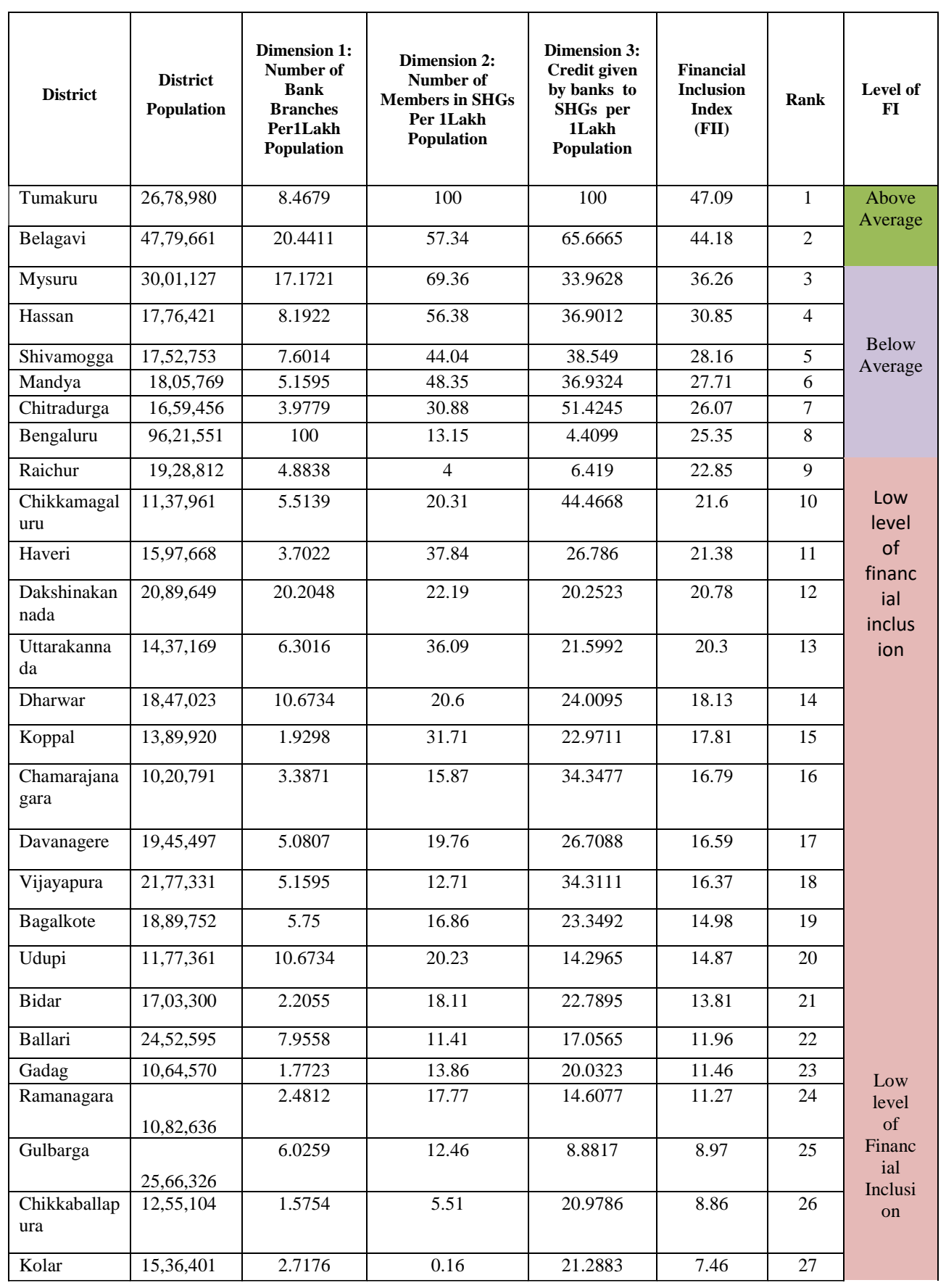


Table 8: Distribution of Districts on the basis of CRISIL Inclusix Scores

\begin{tabular}{c|c|c}
\hline Financial Inclusion Levels & CRISIL Inclusix Score & Number of Districts \\
\hline High & More than 55.0 & Nil \\
\hline Above Average & Between 40.1 and 55.0 & 06 \\
\hline Below Average & Between 25.0 and 40.0 & 22 \\
\hline Low & Less than 25 & \\
\hline
\end{tabular}

Source: Categorized by the author based on the computed values referring to CRISIL inclusix

As depicted in Table 7, only 2 districts have above average level of financial inclusion (47.09, 44.18). 6 districts have below average level of financial inclusion and 22 districts have a very low level of financial inclusion, which shows that the overall level of financial inclusion in the state of Karnataka is not overwhelming.

\subsection{Data Analysis and Discussion:}

Table. 9

\begin{tabular}{|c|c|}
\hline Cronbach'sAlph $^{\mathrm{a}}$ & Cronbach's Alpha Based on Standardized Items $^{-68}$ \\
\hline .684 & .665 \\
\hline
\end{tabular}

a. The value is positive hence reliable

From the above table, it is clear that the data collected has internal consistency, therefore, it is acceptable as the alpha test value is more than 0.68 , hence is reliable for further analysis ( Any value more than .60 or $60 \%$ is acceptance )

\subsection{Test of Hypothesis:}

Hypothesis 1: Chi-square between participation in SHGBLP and accessibility to all the services provided by the financial institutions.

H01: There is no association between participation in SHGBLP and accessibility to all the services provided by the financial institutions

H1: There is an association between participation in SHGBLP and accessibility to all the services provided by the financial institutions 
Table .10 Chi square Table

\begin{tabular}{|l|r|r|r|r|r|}
\hline & Value & \multicolumn{1}{|c|}{ df } & $\begin{array}{c}\text { Asymp. Sig. } \\
\text { (2-sided) }\end{array}$ & $\begin{array}{c}\text { Exact Sig. (2- } \\
\text { sided) }\end{array}$ & $\begin{array}{c}\text { Exact Sig. (1- } \\
\text { sided) }\end{array}$ \\
\hline $\begin{array}{l}\text { Pearson Chi- } \\
\text { Square }\end{array}$ & $1.198^{\mathrm{a}}$ & 1 & .274 & & \\
\hline $\begin{array}{l}\text { Continuity } \\
\text { Correction }\end{array}$ & .701 & 1 & .402 & & \\
\hline $\begin{array}{l}\text { Likelihood } \\
\text { Ratio }\end{array}$ & 1.256 & 1 & .262 & & \\
\hline $\begin{array}{l}\text { Fisher's Exact } \\
\text { Test }\end{array}$ & 1.186 & & & & \\
\hline $\begin{array}{l}\text { Linear-by- } \\
\text { Linear } \\
\text { Association }\end{array}$ & 100 & & .316 & \\
\hline $\begin{array}{l}\text { N of Valid } \\
\text { Cases }\end{array}$ & & & & & \\
\hline
\end{tabular}

\section{Interpretation:}

Chi-square test is used to find whether the two attributes are associated or not. This test is used to find whether one variable has a significant influence over the other variable. Chi-square test was conducted to know whether participation in SHGBLP and accessibility to all the services provided by the financial institutions are independent of each other or dependent, Results of the test reveal that $\mathrm{p}$-value $(0.274)$ is more than 0.5 ( $p>0.5)$, hence we rejected alternative hypothesis $\mathrm{H} 1$ and the null hypothesis is accepted and it is inferred that there is no association between ,i.e. .participation in SHGBLP and accessibility to all the services provided by the financial institutions are independent of each other. 
Hypothesis 2: SHG membership has a positive correlation with savings, Asset ownership and Quick access to loans

Table 11: Correlation Analysis

\begin{tabular}{|c|c|c|c}
\hline & & SHG Membership & Increased Savings \\
\hline SHG Membership & Pearson Correlation & 1 & 1 \\
\hline & Sig. (2-tailed) & & 100 \\
\hline Increased Savings & Pearson Correlation & 100 & .008 \\
\hline & Sig. (2-tailed) & .008 & .939 \\
\hline & $\mathrm{N}$ & 100 & 100 \\
\hline
\end{tabular}

Correlation is a statistical technique that can show whether and how strongly pairs of variables are related. The estimate of a correlation is called the correlation coefficient (or " $r$ "). It ranges from -1.0 to +1.0 . The closer $r$ is to +1 or -1 , the more closely the two variables are related. If the value of $r$ is close to 0 , it means there is no relationship between the variables. If $r$ is positive, it means that as one variable gets larger the other gets larger. If $r$ is negative it means that as one gets larger, the other gets smaller (often called an "inverse" correlation).

\section{Interpretation}

Above table number 10 expresses the correlation between SHG Membership and income of women members of SHGs. From the Correlation results, it can be seen that the correlation coefficient (r) equals .008, with p-value 0.939 .The correlation analysis shows that theoretically there is a positive relationship between SHG membership and Savings. But there is a weak correlation i.e., as SHG member's participation increases the probability of an increase in their savings is comparatively less. 
Table. 12

\begin{tabular}{|c|c|c|c|}
\hline & & SHG Membership & $\begin{array}{c}\text { Increase in asset } \\
\text { ownership? }\end{array}$ \\
\hline SHG Membership & Pearson Correlation & 1 & 1 \\
\hline & Sig. (2-tailed) & & 100 \\
\hline Increase in asset ownership & Nearson Correlation & 100 & -.076 \\
\hline & Sig. (2-tailed) & -.076 & .451 \\
\hline & $\mathrm{N}$ & .451 & 100 \\
\hline
\end{tabular}

\section{Interpretation}

From the above table 12 Correlation results, it can be seen that the correlation coefficient (r) equals -.076, with p-value 0.451. It means that there is a negative correlation between SHG membership and asset owned, it is statistically insignificant as p-value is 0.451 . The correlation analysis shows that theoretically there is a negative relationship between SHG membership and Asset owned i.e as SHG member's participation increases, the probability of an increase in owning assets is comparatively less.

Table .13

\begin{tabular}{|l|c|c|c}
\hline & SHG Membership & SHG Membership & $\begin{array}{c}\text { Participation has enabled } \\
\text { you quick access to your loan }\end{array}$ \\
\hline SHG Membership & Pearson Correlation & 1 & 1 \\
\hline & Sig. (2-tailed) & & 100 \\
\hline Increase in asset ownership & Pearson Correlation & 100 & -.076 \\
\hline & Sig. (2-tailed) & .014 & .451 \\
\hline
\end{tabular}


From the above 13 table Correlation results, it can be seen that the correlation coefficient (r) equals .014, with p-value 0.893 . There is a correlation of 0.893 between membership and quick access to a loan for SHG members, which is statistically significant at $5 \%$ level. The correlation analysis shows that theoretically there is a positive relationship between SHG membership and quick access to a loan. But there is a weak correlation i.e., as SHG member's participation increases the probability of an increase in quick access to loan is comparatively less.

\subsection{Observations}

The present study has analyzed the growth and progress of SHP-BLP in India from 2006-07 to 2016-17, and it was found that still there is a need to cover a larger part of the population which is financially marginalized. The data above in Table- 2 and its corresponding charts highlight that the model has not achieved its goal in its context, the growth is not steady in an escalation of the number of SHGs as well as in the loan or saving amount, even the increment is also meager for most of the years. The present study is undertaken, with an objective to measure the extent of financial inclusion in the state of Karnataka led by Self-help group bank linkage programme by developing a Financial Inclusion Index. The study reveals that the financial inclusion in Karnataka is not overpowering as only 2 districts have above average level, 6 districts are falling under 'below average' and 22 districts are falling under 'low' category of financial inclusion. Most of the SHGs concentration lies only in some states of the country especially in the Southern and Western region; the model should spread in all states of the country. The empirical research study conducted at Belagavi district reveals that most of the SHGs are not credit linked; saving is found to be less attracted to its members. Further many SHGs which are making transactions for several years are not availing the facility of creditlinkage, because they don't have enough knowledge of the process, and lack of accessibility of financial institutions [32]. For overcoming the barrier of remoteness, Business Facilitators and Business Correspondents model should be introduced. Furthermore, ATM, Mobile Banking, and online banking also serve the same purpose of facilitating the accessibility. Though banks have opened considerable numbers of branches in the rural areas including the marginalized section of the society in banking ambit still remains a challenge. BSBDA accounts and Direct Benefit Transfer (DBT) have made considerable growth in including the people who financially excluded. The government of India is attempting to overcome the barrier of "Lack of legal documents" by issuing Aadhaar number to everyone. Now the banks are accepting the Aadhaar card as a legal document for an opening bank account [33]. RBI has identified five target groups of people for improving the financial literacy level and conducted many outbound camps. No Frill and BDSA accounts were created for serving Self-help group members. Though the Government of India and Reserve Bank of India has taken many initiatives to include all the citizens, there is still a considerable percentage of people who are financially excluded due to lack of financial literacy and low or irregular income. Apart from these, people are still approaching private moneylenders for their financial requirements [34]. Just opening an account in banks will not create much impact in the economy. Bankers are rather giving much importance to opening new accounts, than providing loans to financially excluded sections of the society. Therefore, GOI and RBI have to take initiative to provide loans to these people. a) Each Bank branch should adopt a particular rural geographical area through self-help group bank linkage program and extend their service to the people residing in that area. b) Banks may open a special counter for meeting out the needs of these people. c) The Government of India and Reserve Bank of India should formulate a policy for providing small loans to the poor 
people based on their requirements. d) Educational institutions may be included in disseminating financial literacy in the form of including financial knowledge contents in their curriculum. e) Improving employment opportunities for poor people will improve their income. f) Financial institutions can adopt a 50-50 percentage system (Urban and Rural Population coverage) in the implementation of all financial services by the Banks and Financial Institutions

\subsubsection{Novelty}

Considering the penetration of banking services and financial assistance facilitated to SHG, majority districts of Karnataka have a very low level of financial inclusion. As per the results of the statistical analysis done, linking of SHG to formal banking channel and availing the formal banking financial services by the self-help group members is also found to be low.

\subsection{Contribution of this Study}

In the previous studies, financial inclusion index was computed using only selected banking indicators such as, Banking penetration, availability and usage of banking services18. This study has considered the number of members in SHG, and the credit given by banks to the SHG to construct the inclusion index for assessing financial inclusion through SHGBLP .From the policy perspective, financial inclusion index proves to be helpful in measuring the degree of financial exclusion, inequality, income disparity and regional variation in financial inclusion in an economy. The study provides a panoramic view of financial inclusion in India.

\subsection{Scope for Future Research}

- A further research can be conducted to construct the FII at National or regional level, as well as potential demand side and supply side indicators of financial inclusion in Indian context.

- A study on impact of financial inclusion initiatives on the empowerment of rural people can be conducted. As accessibility to financial services should ultimately lead to utilization of credit for productive purposes rather than for consumption purposes for the economic growth of the nation.

- Further research can be conducted on the segment of population who are availing SHG loans through bank linkage program. Region wise study can be undertaken to know the success of reach of this initiative in different regions, and the level of awareness among rural people about this policy initiative can be assessed.

- A study can be conducted to assess the poverty reduction potential of these financial inclusion initiatives like SHGBLP which is the main concern of the program.

- A comparative study can be done vis-à-vis different models of SHG and to know most effective model in meeting the credit needs of the rural poor.

- A Comparative study can be undertaken to assess the impact of SHGBLP in facilitating the access to formal financial channel in the aspects of Savings and Credit. 


\section{References}

[1] Self Help Group Bank Linkage Programme. (2018, August). Retrieved August 2018, from www.rbi.org.in: https://www.rbi.org.in/scripts/BS_ViewMasCirculardetails.aspx?id=9063

[2] www.rbi.org.in. (2018, July). Retrieved July (2018)

[3] Mohammad, Y , Grameen Bank-micro credit and Millennium Development Goals, Economic and Political Weekly, Vol.39, March(2004).

[4] www.nabard.org

[5] HG Bank linkage program as the ultimate inclusion program. (2019). Retrieved from www.nabard.org:

https://www.nabard.org/auth/writereaddata/WhatsNew/1107171727Approved_Final_Press

_Release.pdf

[6] Preface of planning commission. (2017). Retrieved August 2018, from Planningcommission.gov.in:http://planningcommission.gov.in/reports/sereport/ser/stdy_ase e.pdf. 2017.

[7] Ritu Jain, "Socio-Economic Impact through Self Help Groups”, Yojana, Vol. 47, No.7, pp.11-12, (2003)

[8]Sonu Garg, D. P. Financial Inclusion in India- a Review of Initiatives and achievements. IOSR Journal of Management (IOSR-JBM), 52-61, (2014).

[9] Sibi, M. S., \&Ananth, A. A. Banking inclusion -A gateway to financial inclusion. Sumedha Journal of Management, 6(1), 4-19. (2017).

[10] Cnaan, r. A., Moodithaya, M. S., \& Handy, Financial inclusion: Lessons from rural south India. Journal of Social Policy, 41(1), 183-205 (2012).

[11] Sharma, D. (2016). The nexus between financial inclusion and economic growth. Journal of FinancialEconomic Policy, 8(1), 13-36. (2016).

[12] Bammi, R. SHG Bank Linkage: Lending a Helping Hand? Vision: the journal of Business perspective (09722629), 18(3), 237-244. (2014)

[13] Das Gupta, M. Role of Commercial Banks in Self-Help Group-Bank Linkage Programme in India: An Empirical Assessment. Journal of Institute Of Public Enterprise, 38(1/2), 65-81, (2015).

[14] Nanda, K., \& Kaur, M. Bank-led Financial Inclusion and Human Development: Evidence from India. South Asian Journal of Management, 24(1), 114-140, (2017)

[15] Sarma, M. (2008). Index of Financial Inclusion. Working Paper No. 215 ICRIER (2008)

[16] Chattopadhyay, S. K. Financial Inclusion in India: A case-study of West Bengal. RBI Working Paper (2011).

[17] Pal, S. R. Measuring Financial Inclusion: An Axiomatic Approach. Working Paper, IGIDR. (2010).

[18] ManiklalAdhikary, S. B. Journal of Social and Economic Development, (2013) [19] Bhuvana, M., \&Vasantha, S. Self Help Group Bank Linkage Programme- An Index of Measuring Financial Inclusion. Indian Journal of Science and Technology, 9(43), (2014).

[20] Pillai, D., \& Abraham, S. Mediating Role of Self Help Groups for Stimulating Rural Financial Intermediation in India. Journal of Internet Banking and Commerce, 22, 1-11. (2017)

[21] Status of Microfinance in India Report by NABARD (2010-11 to 2016-17) 
[22] SHG Bank linkage program as the ultimate inclusion program. (2019). Retrieved from www.nabard.org:

https://www.nabard.org/auth/writereaddata/WhatsNew/1107171727Approved_Final_Press _Release.pd

[23] Bharat Microfinance Report (2017).

[24] Micro Finance in India 2017-18. (2018, August). Retrieved August 2018, from www,nabard.org:https://www.nabard.org/auth/writereaddata/tender/1907183104SMFI\%20 2017-18.pdf

[25] Sriram, M., \&Sundaram, N. Financial Inclusion Index: A Customized Regional Model with Reference to Economically Most Backward Districts of Tamil Nadu, India. Mediterranean Journal of Social Sciences, 6(6), 209. (2015)

[26] CRISIL Inclusix. Financial Inclusion. (2018, August). Retrieved August 2018, from www.crisil.com: https://www.crisil.com/en/home/our-analysis/reports/2018/02/crisilinclusix-financial-inclusion-surges-driven-by-Jan-Dhan-yojana.html

[27] Pais, M. S. (2008). Financial Inclusion and Development A cross-country analysis. Retrieved (GupteRajani, 2012) August 2018, from icrier.org: M Sarma, J Pais - Annual Conference of the Human Development and ..., 2008 - icrier.org

[28] Census India. (2018, August). Retrieved August 2018, from www.censusindia2011.com: https://www.censusindia2011.com/karnataka-population.html [29] Self Help Group Bank Linkage Programme. (2018, August). Retrieved August 2018, from https://www.rbi.org.in/scripts/BS_ViewMasCirculardetails.aspx?id=9063

[30] Self Help Groups. (2018, August). Retrieved August 2018, from www.nrlm.gov.in: https://nrlm.gov.in/shgOuterReports.do?methodName=showDistrictPage\&encd=15\&stateN ame=KARNATAKA\&reqtrack=JzFeDCAzbraTSnqYI6x739lep

[31] District Wise Report On Shg Group. (2018, August). Retrieved August 2018, from www. panchatranta.kar.nic.in: http://www.panchatantra.kar.nic.in/STAT/shgstat.aspx

[32] Goyal, S. K., Agarwal, S., Gupta, R. B., \& Kumar, S. A Study on the Performance of Self Help Group Bank Linkage Programme in India. BVIMSR's Journal of Management Research, 9(1), 84-90. (2017)

[33] Reddy, G.N. Empowering Women through Self Help Groups and Microcreditee Journal of Rural Development, Vol. 21(4). (2002),

[34] Rao, Srinivasa K Micro Finance to the poor: a Tool for poverty alleviation and women empowerment, The Management Accountant, Vol.2, February (2008), 